\title{
Transmission of Infectious Diseases through Mouth-to-Mouth Ventilation: Evidence-Based or Emotion-Based Medicine?
}

\author{
Carlos Frederico A rend
}

Porto Alegre, RS - Brazil

\begin{abstract}
Cardiopulmonary arrest is the interruption of the heart's mechanical activity confirmed by unconsciousness, apnea, and absence of central pulse ${ }^{1}$. The basic technical knowledge for management of this medical emergency by way of cardiopulmonary resuscitation (CPR) should be part of the training curriculum for health care workers and is highly recommended for the general public. However, concern about the transmission of diseases appears to have created substantial barriers for the use of CPR, both in and out of the hospital setting. The idea that the intention of saving a person's life could result in the death of the rescuer is intimidating and reduces peoples' desire and availability to help cardiopulmonary arrest victims ${ }^{2-5}$. The outcome of reduced use of CPR is reflected in the increase in the morbidity and mortality of the event ${ }^{6-8}$. Studies carried out by Brenner report that about $50 \%$ of physicians would refuse to carry out mouth-to-mouth ventilation in strangers and 7$14 \%$ would not perform mouth-to-mouth ventilation on victims with AIDS ${ }^{9-11}$. Another study reports that, although $68 \%$ of the interviewees would perform chest compressions on an unknown victim of cardiopulmonary arrest, only $15 \%$ would perform mouth-to-mouth ventilation ${ }^{12}$. A number of other papers report similar findings ${ }^{13-17}$. In the great majority of cases, the reason for the reluctance to immediately start CPR is the fear of catching transmissible diseases, especially HIV ${ }^{12,18}$.

The objective of this article is to review the literature on infectious diseases transmitted through mouth-tomouth ventilation. The search for available scientific evidence for pre- and post-exposure prophylaxis has been made through searching the Medline database of articles published between 1990-1999. In addition to this, all the articles published between 1966-1999 in journals indexed to Index Medicus with the key word mouth to mouth ventilation or mouth-to-mouth ventilation, and cardiopulmonary resuscitation were reviewed. Conclusions were also based on a personal collection of articles, posters and relevant notes collected over the last few years.
\end{abstract}

Hospital de Clínicas de Porto Alegre da Faculdade de Medicina da UFRGS. Mailing adress: Carlos Frederico Arend - Av. Nilo Peçanha, 1121/302 - 91330-000 - Porto Alegre, RS
Risk of contracting infectious diseases during mouth-to-mouth ventilation -Virtually any disease transmissible by secretions or blood may be acquired during basic CPR. Adding this knowledge to the natural fear caused by mouth-to-mouth contact with other people, mouthto-mouth ventilation is becoming the object of numerous concerns relative to the safety of the rescuer performing the CPR. In spite of the number of potentially transmissible diseases, only reports of isolated incidents have been published. Since the first medical use of mouth-to-mouth ventilation in $1744^{19}$, only the transmission of tuberculosis, Neisseria meningitidis, Herpes simplex, Helicobacter pylori, Shigella sonnei and Salmonella infantis have been documented. No case of hepatitis or HIV transmission has been described over these 254 years, but due to their emotional impact, they will also be discussed here.

Risk of tuberculosis transmission - Tuberculosis is caused almost exclusively by Mycobacterium tuberculosis and is transmited from person to person via the respiratory route. Transmission is most likely to occur from infected persons who are not on effective antituberculosis therapy, or from those under adequate treatment for less than 2-3 weeks with no clinical signs of improvement ${ }^{20}$. Infectious particles may be expelled during sneezing, coughing, speaking ${ }^{21}$, and expiratory phase of mouth-to-mouth ventilation. Extra pulmonary tuberculosis with open abscesses may also be a rare source of infection ${ }^{22}$. Mycobacterium present in fomites are quickly destroyed by heat and sunlight and do not constitute source of infection ${ }^{20}$.

Less than $1 \%$ of infected persons manifest acute clinical disease. In 5-10\% disease only appears after months, years or decades. The remaining $90-95 \%$ never develop tuberculosis ${ }^{22}$.

The test of choice for the diagnosis of contaminating tuberculosis in the resuscitated victim is the search for acidfast bacilli on smear of sputum carried out on two consecutive days. The tuberculin skin test (PPD) is the preferred method to identify rescuers infected with M. tuberculosis ${ }^{22}$. PPD is not affected or contraindicated during pregnancy ${ }^{23}$. Two to eight weeks are necessary for the tuberculin test to become positive after contamination ${ }^{24}$.

Chemoprophylaxis is indicated after mouth-to-mouth ventilation in victims with positive sputum smears or under antituberculosis therapy for less than 2 weeks (table I) ${ }^{25}$. In 


\begin{tabular}{|lccc|}
\hline \multicolumn{2}{|c|}{ Table $\mathbf{I}$ - Chemoprophylaxis of tuberculosis after mouth-to-mouth ventilation in positive sputum smear patients or in treatment for less than $\mathbf{2}$ weeks } \\
\hline Rescuer at the time of exposure & Medication & Daily dosage & Duration \\
\hline PPD negative & Isoniazid & $10 \mathrm{mg} / \mathrm{kg}$ till $400 \mathrm{mg}$ & $2-6 \mathrm{months} *$ \\
PPD positive & Isoniazid & $10 \mathrm{~m} / \mathrm{kg}$ till $400 \mathrm{mg}$ & $12 \mathrm{mon}$ ths \\
\hline * See text to differentiate the duration of prophylaxis. & & & \\
\hline
\end{tabular}

rescuers PPD negative at the time of exposure, induration $\geq 5 \mathrm{~mm}$ two to eight weeks after the mouth-to-mouth ventilation is considered a positive test and indicative of contamination during resuscitation ${ }^{26}$. In such cases prophylaxis should be extended for six months. If PPD remains negative after two months of exposure, prophylaxis may be suspended. Chemoprophylaxis in initially PPD positive rescuers should be extended for 12 months ${ }^{27}$. Rescuers previously vaccinated should follow the same regimen described in table I, and the PPD is considered positive if $\geq 10 \mathrm{~mm}^{28,29}$. Chemoprophylaxis is not contraindicated during pregnancy. Isoniazid can prevent tuberculosis in 54-88\% of cases ${ }^{30}$.

The utilization of BCG for postexposure prophylaxis is inferior to the algorithm of PPD plus chemoprophylaxis ${ }^{31}$. Some authors advocate routine vaccination of health care workers, especially in places where the tuberculin test is not used systematically and adherence to the treatment is not adequate ${ }^{32}$. International guidelines do not support the use of BCG in health care workers to prevent tuberculosis infection because of (1) unclear effectiveness and (2) adequate protection provided by PPD plus chemoprophylaxis ${ }^{33}$. In previously vaccinated rescuers, no benefit occurs with revaccination after mouth-to-mouth ventilation ${ }^{34}$. The benefits of BCG in persons with positive tuberculin tests are minimum ${ }^{35}$. Vaccination is not indicated for pregnant women or immunocompromised host ${ }^{33}$.

Only one case of tuberculosis transmited during mouth-to-mouth ventilation has been described. It involves a victim of cardiopulmonary arrest with pulmonary tuberculosis that caused primary skin tuberculosis on the left nasolabial fold of the rescuer. No postexposure chemoprophylaxis was administered. Treatment with isoniazid caused remission of the disease and did not leave sequelae in the rescuer ${ }^{36}$.

Risk of Herpes simplex transmission - About $60 \%$ of adolescents ${ }^{37}$ and $85 \%$ of adults have serological evidence of infection by Herpes simplex type I (HSV-1), which is frequently acquired during infancy by contact of herpetic lesions with mucosa or lesioned skin. In addition to this, between 2-10\% of adults have HSV-1 in the saliva without clinical signs of disease ${ }^{38,39}$. Transmission via CPR training mannequim is also possible, as the HSV is capable of surviving for 88 hours in dry gauze and for 1.5 hours on a toilet seat ${ }^{40}$.

The rescuer infected during the mouth-to-mouth ventilation may remain asymptomatic during the acute phase in 99\% of cases. In the remaining, after an incubation period of 3-4 days, gingival stomatitis, fever, or oral vesiculae may appear.
The diagnosis of infection by HSV-1 is essentially clinical and there are no studies to recommend postexposure chemoprophylaxis to prevent HSV transmition. Available therapy only reduce symptoms, especially if initiated in the prodromic phase ${ }^{41}$. Seronegative rescuers or those without history of labial herpes that have been exposed to herpetic lesions during mouth-to-mouth ventilation may use acyclovir soon after contact ${ }^{42}$.

Two cases of HSV-1 transmission during mouth-tomouth ventilation have been described. In both, herpetic lesions were visible in the victim being resuscitated. Both rescuers fully recovered with no sequelae ${ }^{43,44}$. One case of a probable transmission of asymptomatic herpes during CPR training using a mannequim has also been documented and simultaneously published in two journals ${ }^{45,46}$.

Risk of Helicobacter pylori transmission - Prevalence of infection by $H$. pylori in Brazil is approximately $90 \%$ in individuals with digestive symptoms ${ }^{47}$ and $60 \%$ in asymptomatic blood donors ${ }^{48-49}$. Available data suggest that transmission of the microorganism is by personal contact, but no consensus exists as to whether the oral/ fecal or oral/oral route predominates ${ }^{50-52}$. Helicobacter has already been isolated in dental plaque, saliva, gastric juice, and stools ${ }^{53-54}$.

The majority of the persons acutely infected do not have clinical signs of disease ${ }^{53}$. After an unknown period of latency, a minority develop epigastric pain, nausea, vomiting, hematemesis, and transient hypochlorhydria ${ }^{55-56}$. Most infected persons develop chronic gastritis after contamination ${ }^{57}$. Ten to $20 \%$ develop a peptic ulcer during their lifetime and a minority evolve toward either gastric cancer ${ }^{58-62}$, primary lymphoma of the stomach, or both ${ }^{63-65}$.

The best method for diagnosis is obtaining material through endoscopy for histological analysis and culture. Other noninvasive diagnostic methods are the urea test and detection of antibodies in the serum ${ }^{66}$.

No studies are available on the prophylaxis of $H$. pylori transmission after mouth-to-mouth ventilation of contaminated persons, and its utilization should be restricted to experimental protocols. The value of testing for the diagnosis of $H$. pylori infection on the rescuer has not been fully established, but a theoretic benefit does exist eradicating the microorganism in peptic ulcer disease.

Only one case of $H$. pylori transmission during mouthto-mouth ventilation has been described, which involves the rescue of a victim of respiratory arrest ${ }^{67}$.

Risk of Shigella transmission - Shigellosis is a bacterial disease caused by ingestion of Shigella species. 
Asymptomatic carriers are common, which makes the transmission by mouth-to-mouth ventilation possible even in the absence of symptoms.

After one to eight days of incubation dysentery may occur in the acutely infected rescuer, which is generally self-limited to 1-2 weeks even without treatment. Rarely the contamination can evolve with colonic perforation, bacteremia, or other extraintestinal complications ${ }^{68}$.

The recommended diagnostic method is coproculture, wich become positive 24 hours after the beginning of the symptoms.

No studies about Shigella infection prophylaxis after contact with contaminated persons are available, and such usage should be restricted to experimental protocols.

Only one case of Shigella transmission during mouthto-mouth ventilation has been reported ${ }^{69}$. The physician infected with Shigella sonnei recovered soon after the treatment.

Risk of Salmonella transmission - Salmonellosis is an infection caused by ingestion of Salmonella species bacteria. The nontyphoid form is responsible for $98 \%$ of cases, and its transmission is possible in the absence of symptoms.

The most common clinical presentation of acute infection is self-limited gastroenteritis (from two to seven days), which appears after an incubation period of 6-72 hours $^{70}$.

The recommended diagnostic method is coproculture.

No studies exist about Salmonella transmission or prophylaxis after contact with contaminated material, and its use should be restricted to experimental protocols.

One case of Salmonella infants 6,7:r transmited during mouth-to-mouth ventilation that apparently resulted in self-limited gastrointeritis has been reported ${ }^{71}$.

Risk of Neisseria meningitidis infection- Neisseria meningitidis is a commensal organism of the nasopharynx that can cause a wide range of diseases, being meningitis its most common clinical form. Transmittion occurs principally through airbone droplets or close contact.

The colonization of the upper airway tract by menigococci can result in clinical disease after an incubation period from 2-10 days, causing headache, fever, nausea, vomiting, photophobia, and meningismus. In most cases, however, the colonization is asymptomatic and can persist for months. About $2 \%$ to $30 \%$ of persons are asymptomatic carriers in the nonepidemic setting. If we consider a kiss similar to mouth-to-mouth ventilation, about $33 \%$ of rescuers can be colonized by the pathogenic meningococci while performing basic CPR in patients with menigococcal disease ${ }^{72}$. Adults may be immune to $N$. meningitidis due to previous contact with nonpathogenic bacteria that induce cross-reactive antibodies ${ }^{73}$.

The diagnosis of meningitis in the resuscitated victim is made by specific laboratory findings. All cases of menigococcal disease in Brazil have to be reported to the authorities in the first 24 hours after their diagnosis ${ }^{74}$.

Prophylaxis should be given to the rescuer after mouth-to-mouth ventilation in persons with meningococcal disease. Rifampin is the drug of choice, but ceftriaxone and ciprofloxacin can also reduce the colonization of the pharynx in $90 \%$ (table II). Ceftriaxone is the drug of choice in pregnat rescuers. Antimicrobial chemoprophylaxis should be started as soon as possible within 24 hours after the contact.

During epidemics, vaccination of rescuers is also indicated. The quadrivalent vaccine prevents the transmission of serogroups A, C, Y and W-135 when administered as a single $0.5 \mathrm{~mL}$ subcutaneous injection. The serogroups A and $\mathrm{C}$ vaccines have efficacies of $85-100 \%{ }^{77-79}$. Vaccination with serogroups $\mathrm{Y}$ and $\mathrm{W}-135$ induces bactericidal antibody, but clinical protection has not been documented. Protective levels of antibody are reached from 7 to 10 days following vaccination and last 3 years in adults. Vaccination offers little aditional protection to chemoprophylaxis, but can be used as an adjuvant. The vaccination schedule should not be modified in pregnant women. The protective efficacy and immunogenicity of several vaccines against serogroup B range from 57 to $83 \%{ }^{80-82}$. The only one commercially available vaccine against serogroup B has not been used in the majority of countries because conclusive studies are lacking ${ }^{83}$.

At least four cases of meningococcal transmission have followed mouth-to-mouth ventilation ${ }^{84}$.

Theoretic risk of hepatitis $B$ transmission - The B virus (HBV) is mainly found in blood, but also can be isolated in saliva, tears, digestive juices, semen, vaginal secretions, bile and fomites ${ }^{85-89}$, being potentially transmissible during mouth-to-mouth ventilation. HBsAg was found in saliva of $76 \%$ of patients with severe hepatitis and in $81 \%$ of chronic carriers ${ }^{90}$. However, as saliva has a viral load 1000 to 10000 times lower than plasma, the transmission of HBV by contact of contaminated saliva with the oral cavity, even after the induction of microlesions in receptor mucosa, is still a controversial subject ${ }^{91-94}$.

Contact of contaminated blood with the rescuer's oral cavity, open skin lesion, or cornea can result in the transmission of HBV. Percutaneous exposure to blood is the most efficient route of transmission. The risk of HBV contamination is $30 \%$ after exposure to $\mathrm{HBeAg}$-positive blood, and 6\% after contact with $\mathrm{HBe} A g$-negative blood ${ }^{94-96}$. Although the degree of infectivity is best correlated with $\mathrm{HBeAg}$-positivity, any person positive for $\mathrm{HBsAg}$ is potentially infectious. HBsAg can be identified in serum 30 to 60 days after exposure. The incubation period is $45-160$ days. Symptoms are generally insidious, and can follow

\begin{tabular}{|c|c|c|c|}
\hline \multicolumn{4}{|c|}{$\begin{array}{c}\text { Table II - Prophylaxis after mouth-to-mouth ventilation in endemic } \\
\text { cases of meningococcal disease }\end{array}$} \\
\hline Drug & Age & Dosage & $\begin{array}{l}\text { Duration and } \\
\text { route }\end{array}$ \\
\hline Rifampin & Adults & $600 \mathrm{mg}$ bid & 2 days PO \\
\hline Ciprofloxacin & Adults & $500 \mathrm{mg}$ & single dose $\mathrm{PO}$ \\
\hline Ceftriaxone & Adults & $250 \mathrm{mg}$ & single dose IM \\
\hline
\end{tabular}


three directions: 1) a self-limited course, with destruction of the virus and permanent immunity, which happens in $90-$ 95\% of cases; 2) chronic infection, which happens in 5-10\% of cases and 3) fulminating hepatitis, which happens in less than $1 \%$ of cases. Chronic carriers can be identified by persistently positive $\mathrm{HBs} A g$ levels. In these individuals a $20 \%$ risk of dying of cirrhosis and a $6 \%$ lifetime risk of dying of liver cancer exists. The tendency toward chronicity is inversely related to age ${ }^{97}$.

If the rescuer is anti-HBs or anti-HBc positive, no risk of acquiring hepatitis $B$ exists after mouth-to-mouth ventilation. Anti-HBc identifies all persons previously infected, both carriers and those who are not carriers. Anti-HBs identifies previously infected persons, except for carries. None of these markers show particular advantages for groups expected to have carrier rates of less than $2 \%$, such as health care workers ${ }^{98}$. The utilization of these tests in rescuers after mouth-to-mouth ventilation should not delay the institution of chemoprophylaxis. Postexposure prophylaxis is indicated after mouth-to-mouth contact with HBsAg positive persons (table III) ${ }^{33}$. The cleansing of the exposed skin site with sodium hypochloride followed by soap and water is recommended ${ }^{116}$.

The most efficient measure for preventing HBV infection before occupational exposure is the use of vaccine. The two currently available forms (plasma derived or recombinant) have demonstrated similar immunogenecity and efficacy, and do not interfere with other vaccines concurrently being administered ${ }^{99}$. The vaccine derived from plasma can cause Guillain - Barre syndrome after the first dosage. The magnitude of this association is $1: 200,000$ vaccinees.

The usual schedule of vaccination comprises three intramuscular doses, with second and third doses given 1 and 6 months, respectively, after the first. Every single dose consists in administrating 20mg in the deltoid muscle ${ }^{100}$. Between $90-100 \%$ of persons develop protective levels of antibodies after three doses ${ }^{101-108}$, which provides absolute protection against chronic infection or clinical disease for 710 years ${ }^{109-110}$. Anti-HBs testing should be done $1-6$ months after completion of the vaccine series to provide informa- tion on response to the vaccine. Persons who do not respond to the primary vaccine series should complete a second three-dose vaccine series or repeat vaccination until adequate antibody response is obtained ${ }^{111,112}$. The immunogenecity of vaccine is substantially lower if administrated in the butttock ${ }^{113}$. Vaccine series should be initiated within 7 days after exposure of an unvaccined rescuer even if the source of exposure is HBsAg-negative. An alternative schedule of $0,1,2$ and 12 month have been approved more rapid induction of immunity. No clear evidence exists that this alternative regimen offers greater protection than the standart schedule. Vaccination of individuals previously infected by HBV does not cause significant side effect but is not necessary ${ }^{114}$.

The utilization of a specific immunoglobulin for hepatitis B (HBIG) plus vaccine provides protective levels of antibodies for a prolonged period of time. Therefore, HBIG should be given in a dose of $5 \mathrm{ml}$ or $0.06 \mathrm{ml} / \mathrm{kg}$ as postexposure prophylaxis, even though a study has demonstrated that this regimen is not superior to the use of $\mathrm{HBV}$ vaccine alone after exposure to HBsAg-positive blood ${ }^{115}$. The effectiveness of HBIG when administered after 7 days from exposure is unclear. HBIG and vaccine can be administered at the same time but at a different anatomic site, and is not contraindicated in pregnant or postpartum women. A second dose of HBIG should be administrated one month after the first dose if vaccine series are not provided after exposure ${ }^{33}$.

No case of HBV transmition during mouth-to-mouth ventilation has been described. During the CPR training with a mannequim also no case of transmission has been reported, not even when the mannequim was not cleaned between use by different people ${ }^{117}$. Grouping all studies that describe accidental contamination of CPR training mannequim by the saliva of asymptomatic carriers, 55 individuals are reported to have been exposed to HBV, but none of these became infected after six months ${ }^{117-119}$.

Theoretic risk of hepatitis $\mathrm{C}$ transmission - The hepatitis $\mathrm{C}$ virus ( $\mathrm{HCV}$ ) is transmitted primarily through blood-toblood contact. Other forms of contamination are less impor-

\begin{tabular}{|c|c|c|c|c|}
\hline & \multirow{2}{*}{$\begin{array}{l}\text { Rescuer not } \\
\text { vaccinated }\end{array}$} & \multicolumn{3}{|c|}{ Rescuer vaccinated } \\
\hline & & Immune* & Not immune * & Unknown \\
\hline Source HbsAg positive & $\begin{array}{l}\text { One dose of HBIG } \\
\text { and begin vaccination }\end{array}$ & Tranquilization & $\begin{array}{l}\text { A dose of HBIG and re- } \\
\text { vaccination or } 2 \text { doses of HBIG }\end{array}$ & $\begin{array}{l}\text { Test anti-HBs in the rescuer: } \\
\text { 1) If adequate tranquilize; } \\
\text { 2) If inadequate, } 1 \text { dose of } \\
\text { HBIG and vaccine }\end{array}$ \\
\hline Source HBsAg negative & Begin immunization & Tranquilization & Tranquilization & Tranquilization \\
\hline Source Unknown & Begin immunization & Tranquilization & $\begin{array}{l}\text { If high risk source, } \\
\text { treat as HBsAg positive }\end{array}$ & $\begin{array}{l}\text { Test anti-HBs in the rescuer: } \\
\text { 1) If adequate tranquilize; } \\
\text { 2) If inadequate, begin } \\
\text { re-immunization }\end{array}$ \\
\hline
\end{tabular}


tant during mouth-to-mouth ventilation, even though $62 \%$ of chronic carriers may have HVC-positive saliva ${ }^{120-122}$. Sneezes, cough or fomites do not transmit $\mathrm{HCV}^{123}$.

The average incubation period of $\mathrm{HCV}$ after blood-toblood contact is from 7 to 10 weeks. The majority of infected individuals are asymptomatic $(60-70 \%)$, have jaundice (20-30\%) or have nonespecific symptoms, such as anorexia and weakness (10-20\%). Chronic carriers are also common and contamination is possible in the absence of clinical illness. At least $85 \%$ of the chronically infected have a recurrence of the disease, $60 \%$ remain with persistently elevated liver enzimes ${ }^{124}, 20 \%$ develop cirrhosis ${ }^{125}$ and less than $1 \%$ develop primary hepatocellular cancer. Factors that negatively influence the progression of HCV infection include alcohol use, age over 40 years, and male gender ${ }^{126}$.

Three conditions potentiate the risk of HCV transmission during mouth-to-mouth ventilation: 1) an anti-HCVpositive victim; 2) blood present in the victim's mouth and 3 ) blood-to-blood contact. Knowing each one of these risk factors makes it possible to estimate the chance of contamination. The prevalence of anti-HCV in the urban population of a Brazilian city is $1.25 \%{ }^{127}$. Blood visible in the saliva or vomit is present in $7 \%$ of all resuscitations ${ }^{128}$. Microlesions in the oral mucosa can be present in up to $50 \%$ of rescuers, making blood-to-blood contact possible ${ }^{129}$. The average risk of seroconversion after blood-to-blood contact is $1.8 \%$ (0 to $7 \%)^{124,130-132}$. Mitsui et al reported a seroconversion rate of $10 \%$ based on detection of HCV RNA by polymerase chain reaction $(\mathrm{PCR})^{133}$.

A risk calculation of seroconversion due to mouth-tomouth ventilation is about $1: 125,000(1.25 \times 7 \times 50 \times 1.8)$. In the absence of microlesions in rescuers' oral-mucosa, the risk of contamination through mucosa-blood contact cannot be estimated, because only two cases describing this route of contamination are reported ${ }^{134-135}$. Follow-up studies have not documented transmission associated with nonintact skin or mucous membrane exposures.

Anti-HCV can be detected in $80 \%$ of rescuers within 15 days of exposure, in $90 \%$ within 5 months, and in $97 \%$ within 6 months ${ }^{138,139}$. Approximately $10 \%$ of infections will not be detected unless PCR is used to detect HCV RNA ${ }^{97-136}$. The only tests currently approved by the U.S. Food and Drug Administration for the diagnosis of $\mathrm{HCV}$ infection are those that measure anti-HCV, such as the enzyme immunoassay (EIA) and recombinant immunoblot assay (RIBA). The sensitivity of these tests is greater than $97 \%$, but do not distinguish between patients with acute, chronic, or resolved infection. EIA is considered a standart screening test. Aditional testing with a more specific assay, such as RIBA or detection of HCV RNA, reduce the risk of false-positive results in persons who are EIA positive ${ }^{123}$.

$\mathrm{HCV}$ infection can be diagnosed by detecting either anti-HCV or HCV RNA. Anti-HCV is recommended for routine use in asymptomatic persons, and should include use of both EIA and confirmatory testing with an aditional, more specific assay. Persons who are either EIA anti-HCV negative or EIA anti-HCV positive with negative supple- mental test are considered uninfected, unless other evidence exists to indicate HCV infection (eg., abnormal ALT level with no other etiology). Indeterminate supplemental test results have been observed in persons chronically or recently infected. Confirmation or exclusion of HCV infection in these cases should be made on basis of repeating the anti-HCV in 2 months or testing for HCV-RNA and ALT level ${ }^{137}$.

For rescuers exposed to anti-HCV-positive material, by blood-to-blood or mucosa-to-blood contact, EIA anti$\mathrm{HCV}$ and ALT tests should be performed at the time of exposure and at six months ${ }^{136}$. The HCV RNA can be performed 4-6 weeks after exposure if an early diagnosis is required. The algorithm for detecting asymptomatic infection after contact with anti-HCV-positive blood is found in figure $1{ }^{137}$. Experimental data suggest that $\mathrm{HCV}$ infection does not offer immunity against re-infection ${ }^{140,141}$.

No vaccine is available to prevent hepatitis C. Animal data are confliting about using immune globulin (IG) in HCV prophylaxis. Some studies show protection ${ }^{142-144}$ while other do not ${ }^{145}$. IG is not recommended for postexposure prophylaxis in humans because adequate evidence are lacking ${ }^{136}$.

There is no data to support postexposure use of interferon to prevent $\mathrm{HCV}$ infetion ${ }^{136,146-148}$, though there may be a role for early interferon therapy. At least six health care workers acutely infected received early interferon therapy and cleared $\mathrm{HCV}{ }^{149,150}$. Determination of wheter treatment of HCV infection is more benefical in the acute phase than in the early chronic phase will require aditional studies.

In the absence of pre- and postexposure prophylaxis, specific recommendations for the prevention of HCV transmission, and effective therapy for most persons with chronic hepatitis $\mathrm{C}$, the overall public health benefit associated with the identification of HCV infection in rescuers will be limited. On an individual level, medical and legal issues may be important. Anti-HCV-positive rescuers should refrain from donating blood, organs, tissues and semen, and should not share shaving blades and toothbrushes.

No case of contamination by HCV after mouth-tomouth ventilation has been described. Transmission of $\mathrm{HCV}$ using CPR mannequim have not been reported even though 23 persons have been accidentally exposed to contaminated saliva during training ${ }^{151}$.

Theoretic risk of HIV transmission - Mouth-tomouth ventilation can result in saliva exchange between the victim and the rescuer. This exchange is not implicated in the transmission of HIV, not even when contaminated saliva comes into contact with open wounds ${ }^{152-155}$. Although saliva, sweat and tears do not transmit HIV, blood surely does. Other bodily fluids are also implicated in HIV transmission, but as the contact with these fluids is unlikely during mouth-to-mouth ventilation they will not be discussed here.

The theoretic risk of HIV transmission can be estimated in a similar way as the British population is estimated ${ }^{156}$. 
Conceptually, three conditions potentially transmit HIV: 1) an HIV-positive victim; 2) visible blood in the victim's oral cavity and 3) blood-to-blood contact. The prevalence of HIV in the adult Brazilian population (between 15 and 49 years old) is $0.6 \%{ }^{157}$; in children ( $<15$ years old) and elderly people ( $>49$ years old) it is $0.1 \%{ }^{157,158}$. Blood visible in the saliva or vomit is present in $7 \%$ of all resuscitations ${ }^{128}$. Microlesions in the oral mucosa can be present in $50 \%$ of healthy rescuers, making blood-to-blood contact possible ${ }^{129}$. The average risk of seroconversion after percutaneous exposure to HIV-infected blood is $0.3 \%{ }^{159,160}$.

A risk calculation of seroconversion through mouthto-mouth ventilation can be estimated as: (a) 1:1,580,000 in the rescue of an adult in the general population $(0.6 \times 7 \times$ $50 \times 0.3$ ); (b) 1:9,500,000 in the rescue of a child or an older person in the general population $(0.1 \times 7 \times 50 \times 0.3)$; (c) $1: 9,500$ in the rescue of a known HIV-positive victim (100x $7 \times 50 \times 0.3)$; (d) 1:650 in the rescue of a known HIV-positive victim with visible blood in the oral cavity $(100 \times 100 \times 50 \times 0.3)$.

In the absence of microlesions in the oral mucosa of the rescuer, the theoretic risk of transmission is 1:4,600,000 in an adult rescue and 1:28,000,000 in a child rescue, as the rate of seroconversion after mucosa-blood contact can be estimated in $0.1 \%{ }^{161}$. In spite of individual reports of HIV transmission by skin-blood contact ${ }^{162}$, the risk of seroconversion can not be quantified because this type of contamination has not been reported in prospective studies. Considering that survival rates of atempted CPR outside the hospital setting are $12 \%{ }^{163}$, one HIV-infected rescuer will develop for every 500,000 adults successfully resuscitated. This risk is greater in deep cut, large quantity of contaminated blood, prolonged exposure to HIV and terminal AIDS victim ${ }^{154,164}$. The utility of viral load measurements from a source victim for assessing transmition risk is unknown. Plasma viral load measurement reflects only the level of cell-free virus in the peripheral blood. This measurement does not reflect cell-associated virus in the peripheral blood or the level of virus in other compartiments.

The above estimates may appear empty if not compared with other situations. The risk of death by anaphylactic shock after penicillin use, for example, is 1:50,000. In addition, no case of HIV transmission through mouth-tomouth ventilation has been documented while it has been reported that two persons have probably been infected through kissing ${ }^{165,166}$.

The very low frequency with which HIV has been transmitted by the oral route is impressive. This is probably due to the risk of infection may depend on the size of innoculum, which is frequently very small by oral-to-oral route. The findings of inhibitory substances in saliva may further reduce the risk of infection and cannot be considered in our numerical estimatives. Complete inactivation of HIV by saliva may require 30 minutes of exposure ${ }^{167}$, which makes the role of these substances unclear.

About $95 \%$ of health care workers who seroconvert do so within 6 months after exposure. The consensual recommendation is to perform HIV-antibody testing right after the exposure, at 6 weeks, 12 weeks, and 6 months. If the HIV serostatus of the source patient is unknown consent should be obtained and the person tested for serological evidence of HIV infection.

Wounds and skin sites that have been in contact with body fluids should be washed with soap and water ${ }^{164}$; mucous membranes should be flushed with water or sterile solution ${ }^{164,169,170}$. There is no evidence to support the use of antiseptics, caustic agents or desinfectants as a postexposure prophylaxis. Squeezing the site of contact will not reduce the risk of HIV transmission.

Animal data demonstrated the importance of starting chemoprophylaxis as son as possible ${ }^{171,172}$, and even its

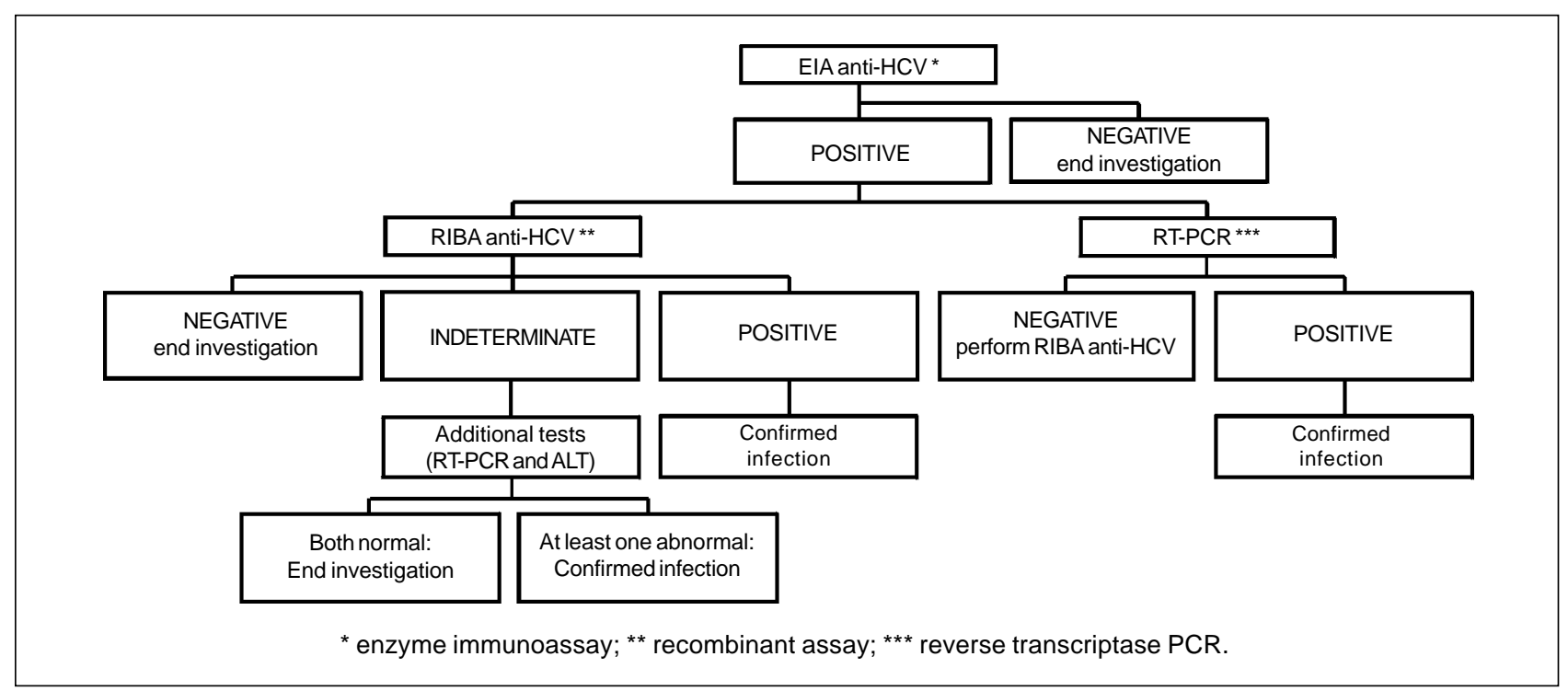

Fig. 1 - HCV infection testing algorithm for asymptomatic persons, to be performed right after exposure and at 6 months. 
ineffectiveness when started later than 24-36h postexposure ${ }^{173-175}$. The regimen indicated for use after contact with HIV-positive blood during mouth-to-mouth ventilation is in fig 2. If the victim is HIV-negative and does not have clinical evidence of AIDS or symptoms of HIV infection, the investigation can be terminated. The follow-up of HIVnegative source at the time of CPR, but who engaged within the last 6 months in behaviours that pose a risk of infection is of unproven benefit.

There is insufficient evidence to recomend a highly effective regimen for all exposures, and two are povided: a "basic" that should be used in most cases, and an "expanded" that should be reserved for exposures that pose an increased risk of transmission (table IV) ${ }^{164}$.

From all antiviral agents, only zidovudine (ZDV), has been shown to prevent HIV transmission in humans ${ }^{176,177}$, reducing the risk of infection by $81 \%{ }^{178}$. No data address wheter adding other drugs provides additional benefit. However, combination therapy have proved superior to monotherapy in reducing HIV titers in infected patients ${ }^{179,180}$. Based on theoretical grounds, a combination of drugs with activity at different stages in viral cycle could offer an additive effect in chemoprophylaxis, particularly for high risk exposures. ZDV is not contraindicated during pregnancy ${ }^{181-183}$. The long-term safety of lamivudine (3TC) is not known in pregnant women ${ }^{184,185}$. No studies have been conducted to determine the effects of the protease inhibitors (IDV) during pregnancy.

An important consideration is that ZDV at doses of $1000-1200 \mathrm{mg}$ per day cause side effects that result in $30 \%$ to discontinue drug. Common symptoms include nausea, vomiting, and headache. All side effects reverse when ZDV is discontinued ${ }^{186-188}$. Multiple drug regimen also cause $30 \%$ to discontinue chemotherapy ${ }^{189-192}$. Side effects can be managed reducing dosage, treating symptoms, or discontinuing drug ${ }^{164}$.

\section{Discussion}

The importance of ventilation during cardiopulmonary resuscitation has been accepted over the centuries. The prophet Elisha may have performed the first mouth-tomouth ventilation as described in the Bible ${ }^{192}$. The first medical report of successful CPR was the rescue of a miner in $1744{ }^{19}$. From that time on, several forms of assisted ventilation have been tested until the midtwentieth century when Safar et al. demonstrated that mouth-to-mouth ventilation was superior to the manual methods used until that time ${ }^{193-195}$. Based on these studies, mouth-to-mouth ventilation has become the therapy of choice for out-ofhospital respiratory arrest by 1960 s.

In more recent years, concerns about the transmission of diseases have created significant barriers for the use of mouth-to-mouth ventilation either inside or outside of the hospital setting, decreasing the willingness of persons to help victims of cardiopulmonary arrest. These facts have brought into question the real necessity for this type of ventilation, in view of the fact that 10 out of 16 cases of transmission of diseases during CPR occurred during mouth-to-mouth. As a justification for such questioning, two additional sources of oxygen for the victim of cardiopulmonary arrest have been cited: gasping and compression-induced ventilation. Animal data show that adequate ventilation can be achieved by chest compression alone, suggesting that mouth-to-mouth may not be critical during CPR. However, the thoraxes of pigs and dogs are more compliant than the human thorax, and the result of these studies should be interpreted with caution. Studies in humans do not report adequate fluxes in the airway during chest compression ${ }^{195,196}$. In addition, sternal thoracic compression provokes progressive pulmonary disinsulfflation and increases hypoxemia in the absence of gasping or mouth-to-mouth ventilation in prolonged CPR. Active compression/decompression generates adequate ventila-

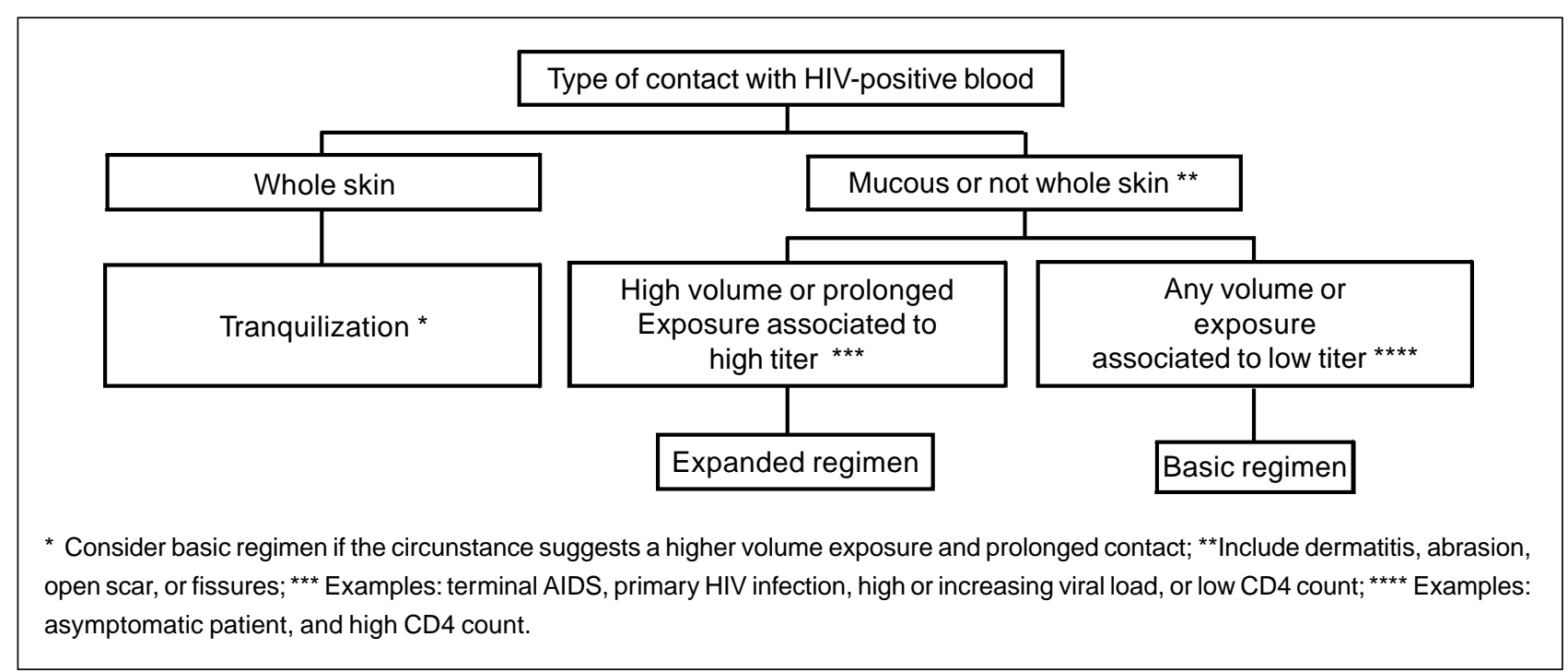

Fig. 2 - Choice of chemoprophylaxis for the transmission of HIV after mouth-to-mouth. 


\begin{tabular}{|c|c|}
\hline Regimen category & Medication \\
\hline Basic & 4 weeks of zidovudine $600 \mathrm{mg}$ per day (300mg bid or $200 \mathrm{mg}$ tid or $100 \mathrm{mg}$ every 4 hours) plus lamivudine $150 \mathrm{mg}$ bid \\
\hline Expanded & Basic regimen plus indinavir $800 \mathrm{mg}$ tid* or nelfinavir $750 \mathrm{mg}$ tid** \\
\hline
\end{tabular}

tion in the absence of intubation or mouth-to-mouth ventilation ${ }^{197}$, but new studies are necessary to evaluate the clinical applicability of these findings.

In spite of these physiological considerations, the major impact is the mortality of cardiopulmonary arrest victims who receive only thoracic compressions, compared with victims who receive compression plus mouth-tomouth. In this regard, numerous are the articles with animal models, but rare are the studies in humans. In an observational study, long term survival of those treated with chest compression plus mouth-to-mouth ventilation and those treated with chest compression alone was comparable $(16 \%$ and $15 \%$, respectively) ${ }^{198,199}$. Notwithstanding the praiseworthy initiative of the authors, the study does not have a definitive design, and it is subjected to criticism. While awaiting new studies in humans, the use of mouth-to-mouth ventilation remains a standart part in the management of cardiopulmonary arrest.

Transmission of infectious diseases during CPR are generally focused on the rescuer, but the victim's risk deserves consideration too. Only one report was found describing this type of contamination, which involved HSV transmission during ventilation through an endotracheal tube ${ }^{200}$. Rescuers that carry potentially contagious diseases should not perform mouth-to-mouth, if mechanical ventilation devises or other trained persons are available. Otherwise, the benefits from CPR overcomes the theoretic risk of disease transmission from the rescuer to the victim, and vice-versa ${ }^{201}$. The utilization of gloves and protective glasses reduces contact with contaminating material, and their use should be part of routine emergency management. The utilization of barrier methods does not provide full protec- tion as is evidenced by the transmission of Streptococcus pyogenes to a fireman in 1991 during ventilation using a bag-valve-mask apparatus ${ }^{202}$.

In summary, the person who witnesses a cardiopulmonary arrest should to be guided by ethics and morality in the rescue. The fact that the rescuer does not wish to perform mouth-to-mouth ventilation when blood is visible does not remove the responsibility to call for help, open the airway ${ }^{205}$, and perform chest compression. Provision of sternal compressions without mouth-to-mouth ventilation is far better than not perform resuscitation at all ${ }^{198}$. In the event that the rescuer decides to follow international guidelines and carry out mouth-to-mouth ventilation ${ }^{1,203,204}$, it is necessary to accompany the victim after initiation of advanced life support to check out the presence of contagious diseases that require postexposure prophylaxis. Drug prophylaxis should be precociously started, and the exposure to contaminated blood or saliva during mouth-to-mouth should be treated as a medical emergency. An overall view of the diseases transmited during mouth-to-mouth ventilation is provided in table $\mathrm{V}$.

The approach to risk of transmission of diseases involves several key issues before and after exposure. A careful preexposure plan should include teaching of basic CPR, knowledgement of the actual risks of infection, preexposure prophylaxis, and utilization of universal precautions to avoid contact with infected material. The postexposure care should include diagnostic tests, prophylaxis, follow-up, and counseling for helping the rescuer to deal with the tremendous anxiety associated with the risk of transmission of infectious diseases. A complete understanding comprising all of these measures should result in an

\begin{tabular}{|c|c|c|c|c|}
\hline Cause & Latency & Symptoms & $\begin{array}{l}\text { Preexposure } \\
\text { prophylaxis }\end{array}$ & $\begin{array}{l}\text { Postexposure } \\
\text { prophylaxis }\end{array}$ \\
\hline Mycobacterium tuberculosis & variable & Variable. Majority asymptomatic & BCG not proved & isoniazid \\
\hline Herpes simplex & 3-4 days & $\begin{array}{l}\text { Gingival stomatitis and fever. } \\
\text { Asymptomatic in } 99 \%\end{array}$ & unknown & $\begin{array}{l}\text { acyclovir to } \\
\text { decrease symptoms }\end{array}$ \\
\hline Helicobacter pilory & unknown & $\begin{array}{l}\text { Nausea, vomiting, epigastric pain } \\
\text { and hematemesis. Majority asymptomatic }\end{array}$ & unknown & unknown \\
\hline Shigella sonnei & $1-8$ days & Self-limited dysentery & unknown & unknown \\
\hline Salmonella infantis 6,7:r & 6-72 hours & Self-limited dysentery & unknown & unknown \\
\hline Neisseria meningitidis & 2-10 days & $\begin{array}{l}\text { Headache, fever, and meningismus. } \\
\text { Majority asymptomatic }\end{array}$ & $\begin{array}{l}\text { vaccine during } \\
\text { outbreaks }\end{array}$ & rifampin \\
\hline
\end{tabular}


increased willingness of laypersons and physicians to perform mouth-to-mouth ventilation on victims of cardiac arrest and, eventually, in a higher rate of successful resuscitations.

\section{Aknowledgement}

Dra. Eliana de Andrade Trotta for reviewing the mannuscript.

\section{References}

1. Comissão Nacional de Ressuscitação Cardiorrespiratória da Sociedade Brasileira de Cardiologia. Consenso Nacional de Ressuscitação Cardiorrespiratória. Arq Bras Cardiol 1996; 66: 377-402.

2. De Bard ML. Cardiopulmonary resuscitation: analysis of six years' experience. Emergency Cardiac Care Committee of the American Heart Association. Risk of infection during CPR training and rescue: supplemental guidelines. JAMA 1989; 262: 2714-5.

3. Ornato JP, Hallagan LF, McMahan SB, Peeples EH, Rostafinski AG. Attitudes of BLS instructors about mouth-to-mouth resuscitation during the AIDS epidemic. Ann Emerg Med 1990; 19: 151-6.

4. Smyser MS, Bryce J, Joseph JG. AIDS related knowledge, attitudes and precautionary behaviors among emergency medical professionals. Public Health Rep 1990; 105: 496-504.

5. Joint Working Party of the Hospital Infection Society and the Surgical Infection Study Group. Risks of surgeons and patients from HIV and hepatitis: guidelines on precautions and management of exposure to blood or body fluids. Br Med J 1992; 305: 1337-43

6. Lee KH, Angus DC, Abramson NS. Cardiopulmonary resuscitation: what cost to cheat dead ? Crit Care Med 1996; 24: 2046-52

7. Weston CF, Wilson RJ, Jones SD. Predicting survival from out-of-hospitalcardiac arrest: a multivariate analysis. Resuscitation 1997; 34: 27-34.

8. Eisenberg MS, Bergner L, Hallstrom A. Cardiac resuscitation in the community. Importance of rapid provision and implications for program planning. JAMA 1979; 241: 1905-7.

9. Brenner B, Stark B, Kauffman J. The reluctance of house staff to perform mouth-tomouth resuscitation in the inpatient setting: what are the considerations? Resuscitation 1994; 28: 185-93.

10. Brenner BE, Kauffmann J. Response to cardiac arrests in a hospital setting: delays in ventilation. Resuscitation 1996; 31: 17-23.

11. Brenner BE, Kauffman J. Reluctance of internists and medical nurses to perform mouth-to-mouth resuscitation. Arch Intern Med 1993; 153: 1763-9.

12. Locke CJ, Berg RA, Sanders AB, et al. Bystander cardiopulmonary resuscitation. Concerns about mouth-to-mouth contact. Arch Intern Med 1995; 155: 938-43.

13. Currey CJ, Johnson M, Ogden B. Willingness of health-professionals to treat patients with AIDS. Acad Med 1990; 65: 472-4

14. Seard T. Going face to face with fear. Nursing 1990; 20: 43

15. Blumenfield M, Smith PJ, Milazzo J, Seropian S, Wormser GP. Survey of attitudes of nurses workiing with AIIDS patients. Gen Hosp Psychiatry 1987; 9: 58-63.

16. Prosser RL Jr. Cardiopulmonary resuscitation training and risk of infection. JAMA 1990; 263: 3025.

17. Ornatto JP. Providing CPR and emergency care during the AIDS epidemic. Journal of Emergency Care and Transportation: Emergency Medical Services 1989; 18: 45-50.

18. McNeil EL. Re-evaluation of cardiopulmonary resuscitation. Resuscitation 1989; 18: 1-5

19. Bertechhi CE. Cardiopulmonary resuscitation: An element of sophistication in the 18th century. Am J Hert J 1980; 100: 580-1

20. Dooley Jr SW, Castro KG, Hutton MD, et al. Guidelines for Preventing the Transmission of Tuberculosis in Health-Care Settings, with Special Focus on HIV-Related Issues. MMWR Morb Mortal Wkly Rep 1990; 39(RR-17): 1-29.

21. Hutton MD, Stead WW, Cauthen GM, et al. Nosocomial transmission of tuberculosis associated with a draining tuberculous abscess. J Infect Dis 1990; 161: 286-95

22. American Thoracic Society/CDC. Diagnostic standards and classification of tuberculosis. Am Rev Respir Dis 1990; 142: 725-35.

23. Snider D. Pregnancy and tuberculosis. Chest 1984; 86(suppl): 10S-13S

24. Gutierrez RS, Ott WP, Silva LCC da, Hetzel JL, Picon PD, Porto NS. Tuberculose. In: Silva LCC, ed. Compêndio de Pneumologia. São Paulo: Fundo Editorial Byk 1993: 539-79.

25. Palombini BC, Hetzel JL, Silva LCC da. Tuberculose. In Duncan BB, Schmidt MI, Giugliani ERJ, eds. Medicina ambulatorial: condutas clínicas em atenção primária. $2^{a}$ ed. Porto Alegre: Artes Médicas Sul, 1996: 352-8.
26. CDC. Essential components of a tuberculosis prevention and control program; and Screening for tuberculosis and tuberculosis infection in high-risk populations: recommendations of the Advisory Council for the Elimination of Tuberculosis. MMWR Morb Mortal Wkly Rep 1995; 44 (RR-11): 1-34.

27. Wannmacher L. Antituberculosos. In: Fuchs FD, Wannmacher L. eds. Farmacologia Clínica: Fundamentos da Terapêutica Racional. Rio de Janeiro: Guanabara Koogan, 1998: 266-71.

28. CDC. Guidelines for preventing the transmission of Mycobacterium tuberculosis in health-care facilities, 1994. MMWR MMWR Morb Mortal Wkly 1994; 43(RR-13): 1-132.

29. CDC. The role of BCG vaccine in the prevention and control of tuberculosis in the United States: a joint statement by the Advisory Council for the Elimination of Tuberculosis and the Advisory Committee on Immunization Practices. MMWR Morb Mortal Wkly Rep 1996; 45(RR-4): 1-18.

30. Comstock GW, Woolpert SF. Preventive therapy. In: Kubica GP, Wayne LG, eds. The Mycobacteria: A Sourcebook. New York: Marcel Dekker Inc 1984: 1071-82.

31. Jordan TJ, Montgomery RL, Mangura B, Reichman LB. BCG in tuberculosis prevention: A decision analysis addressing inoculation of U.S. house officers in light of multiple drug-resistant strains. Am J Respir Crit Care Dis 1994; 149: A 855 .

32. Greenberg PD, Lax KG, Schechter CB. Tuberculosis in house staff: a decision analysis comparing the tuberculin screening strategy with the BCG vaccination. Am Rev Respir Dis 1991; 143: 490-5.

33. CDC. Immunization of Health-Care Workers: recommendations of the Advisory Committee on Immunization Practices (ACIP) and the Hospital Infection Control Practices Advisory Committee (HICPAC). MMWR Morb Mortal Wkly Rep 1997; 46(RR-18): 1-42.

34. World Health Organization. Global Tuberculosis Programme and Global Programme on Vaccines. Statement on BCG revaccinnation for prevention of tuberculosis. Wkly Epidemiol Rec 1995; 32: 229-31.

35. Cohn DL. Use of Bacille Calmette-Guérin vaccination for the prevention of tuberculosis: renewed interest in na old vaccine. Am J Med Sci 1997; 313: 372-6.

36. Heilman KM, Muschenheim C. Primary cutaneous tuberculosis resulting from moth-to-mouth respiration. N Eng J Med 1965; 273: 1035-6.

37. Rosenthal SL, Stanberry LR, Biro FM, et al. Seroprevalence of herpes simplex virus types 1 and 2 and cytomegalovirus in adolescents. Clin Infect Dis 1997; 2: 135-9.

38. Junior DRG, Cough RB. A prospective study of chronic herpes simplex virus infection and recurrent herpes labialis in humans. J Immunol 1970; 104: 289-95.

39. Hatherly LI, Hayes K, Jack I. Herpes virus in an obstetric hospital. II: Assintomatic virus excretion in staff members. Med J Aust 1980; 2: 273-5.

40. Larson T, Bryson Y. Fomites and herpes simplex virus: the toilet seat revisited. Pediatr Res 1982; 16: 244.

41. Machado ARL. Antivirais. In: Fuchs FD, Wannmacher L. eds. Farmacologia Clínica: Fundamentos da Terapêutica Racional. Rio de Janeiro: Guanabara Koogan SA, 1998: 295-6.

42. Mejicano GC, Maki DG. Infections acquired during cardiopulmonary resuscitation: estimating the risk and defining strategies for prevention. Ann Intern Med 1998; 129: 813-28.

43. Hendricks AA, Shapiro EP. Primary herpes simplex infection following mouthto-mouth resuscitation. JAMA 1980; 3: 257-8.

44. Finkelhor RS, Lampman JH. Herpes simplex infection following cardiopulmonary resuscitation. JAMA 1980; 7: 650 .

45. Mannis MJ, Wendel RT. Transmission of herpes simplex during cardiopulmonary resuscitation training. Compr Ther 1984; 10: 15-7.

46. Mannis MJ, Wendel RT. Transmission of herpes simplex during cardiopulmonary resuscitation training. Ann Ophthalmol 1984; 16: 64-6.

47. Bezerra J de M, Vale AV, Lobato Filho JC, et al. Helicobacter pylori gastric infection in symptomatic patients from São Luís Island, MA: endoscopic, anatomicopathologic and microbiological correlations. Rev Soc Bras Med Trop 1996; 3 : 245-50. 
48. Rocha GA, Queiroz DM, Mendes EN, et al. Indirect immunofluorescence determination of the frequency of anti-H. pylori antibodies in Brazilian blood donors. Braz J Med Biol Res 1992; 7, 683-9.

49. Oliveira AM, Queiroz DM, Rocha GA, Mendes EN. Seroprevalence of Helicobacter pylori infection in children of low socioeconomic level in Belo Horizonte, Brazil. Am J Gastroenterol 1994; 12: 2201-4.

50. Matysiak Budnik T, Mégraud F. Epidemiology of Helicobacter pylori infection with special reference to professional risk. J Physiol Pharmacol 1997; 48(suppl 4): 3-17.

51. Mégraud F. Transmission of Helicobacter pylori: faecal-oral versus oral-oral route. Aliment Pharmacol Ther 1995, 9(suppl 2): 85-91.

52. Achiron A, Pinhas-Hamiel O, Barak Y, et al. Oral carriage of Helicobacter pylori: a review. J Periodontol 1997; 1: 2-6.

53. Cave DR. Transmission and epidemiology of Helicobacter pylori. Am J Med 1996; 100: 5A, 12S-17S

54. Madinier IM, Fosse TM, Monteil RA. Oral Carriage of Helicobacter pylori: a review. J Periodontol 1997: 1; 2-6.

55. Goodwin CS, Worsley BW. Microbiology of Helicobater pylori. Gastroenterol Clin N Am 1993; 22: 5-19

56. American Academy of Pediatrics - Helicobacter pylori Infections. In: Peter G, ed. 1997 Redbook: Report of the Committee on Infectious Diseases. $24^{\text {th }}$ ed. Elk Grove Village: American Academy of Pediatrics 1997: 231-2.

57. Kuipers EJ. Helicobacter pylori and the risk and management of associated diseases: gastritis, ulcer disease, atrophic gastritis and gastric cancer. Aliment Pharmacol Ther ; 11( suppl 1):71-88.

58. Asaka M, Takeda H, Sugiyama T, Kato M. What role does Helicobacter pylori play in gastric cancer? Gastroenterology 1997; 113(6 suppl): S56-60.

59. Forman D, Newell DG, Fullerton F. Association between infection with Helicobacter pylori and risk of gastric cancer: evidence from prospective investigation. Br Med J 1991; 331: 1302-5.

60. Parsonnet J, Friedman GD, Vandersteen DP, et al. Helicobacter pylori infection and the risk of gastric carcinoma. N Engl J Med 1991; 325: 1127-31.

61. Nomura D, Stemmerman GN, Chyou PH, et al. Helicobacter pylori infection among Japonese Americans living in Hawaii. N Engl J Med 1991; 325: 1132-6.

62. Forman D, Webb P, Parsonnet J. H. pylori and gastric cancer. Lancet 1994; 343 : 243-4.

63. Eidt S, Stolte M, Fischer R. Factors influencing lymph node infiltration in primary gastric malignant lymphoma of the mucosa: immune response to Campylobacter pylori? J Clin Pathol 1989; 42: 1269-71.

64. Wotherspoon AC, Ortiz-Hidalgo C, Falzon MR, Isaacson PG. Helicobacter pylori-associated gastritis and primary B-cell gastric lymphoma. Lancet 1991; 338: 1175-6.

65. Parsonnet J, Hansen S, Rodriguez L, et al. Helicobacter pylori infection and gastric lymphoma. N Engl J Med 1994; 330: 1267-71.

66. Mégraud F. How should Helicobacter pylori infection be diagnosed? Gastroenterology 1997; 13(suppl 6): S93-8.

67. Figura N. Mouth-to-mouth resuscitation and Helicobacter pylori infection. Lancet 1996; 347: 1342.

68. Keusch GT. Shigellosis. In: Isselbacher KJ, Braunwald E, Wilson JD, Martin JB, Fauci AS, Kasper DL. eds. Harrison's Principles of Internal Medicine. International edition.: McGraw-Hill Inc, 1994: 678.

69. Todd MA, Bell JS. Shigellosis from cardiopulmonary resuscitation. JAMA 1980; 4: 331.

70. Ashkenazi S, Cleary TG. Salmonella infections. In Behrman RE, Kliegman RM, Arvin AM, Nelson WE. eds. Nelson Textbook of Pediatrics. International edition: Philadelphia: WB Sauders Co., 1996: 784-8.

71. Ahmad F, Senadhira DC, Charters J, Acquilla S. Transmission of Salmonella via mouth-to-mouth resuscitation. Lancet 1990; 335: 787-8.

72. Kristiansen B-E, Tveten Y, Jenkins A. Which contacts of patients with meningococcal disease carry the pathogenic strain of Neisseria meningitidis? A population based study. Br Med J 1998; 317: 621-5.

72. Griffiss JM. Meningococcal infections. In: Isselbacher KJ, Braunwald E, Wilson JD, Martin JB, Fauci AS, Kasper DL. eds. Harrison's Principles of Internal Medicine. International edition.: McGraw-Hill Inc., 1994: 200.

73. Ministério da Saúde. Guia de vigilância epidemiológica. Brasília, CENEPI/FNS, 1994.

74. American Academy of Pediatrics. Meningococcal infections. In: Peter G, ed. 1997 Redbook: Report of the Committee on Infectious Diseases. $24^{\text {th }}$ ed. Elk Grove Village: American Academy of Pediatrics, 1997: 357-62.

75. Barroso DE. Doença meningocócica: epidemiologia e controle dos casos secundários. Rev. Saúde Pública 1998; 32: 89-97.

76. CDC. Control and prevention of meningococcal disease and Control and prevention of serogroup $\mathrm{C}$ meningococcal disease: evaluation and management of suspected outbreaks: recommendations of the Advisory Committee on Immunization Practices (ACIP). MMWR Morb Mortal Wkly Rep 1997; 46(RR5): $1-21$.
77. Pinner RW, Onyango F, Perkins BA, et al. Epidemic meningococcal disease in Nairobi, Kenya, 1989. J Infect Dis 1992; 166: 359-64.

78. Sippel JE. Meningococci. Crit Rev Microbiol 1981; 8: 267-302.

79. Cochi SL, Markowitz LE, Joshi DD, et al. Control of epidemic group A meningococcal meningitis in Nepal. Int J Epidemiol 1987; 16: 91-7.

80. Sierra GVG, Campa HC, Varcacel NM, et al. Vaccine against group B Neisseria meningitidis: protection trial and mass vaccination results in Cuba. NIPH Ann 1991;14: 195-207.

81. Bjune G, Høiby EA, Gronnesby JK, et al.Effect of outer membrane vesicle vaccine against group B meningococcal disease in Norway. Lancet 1991; 338: 1093-6.

82. Boslego JB, Garcia J, Cruz C. Efficacy, safety, and immunogenicity of a meningococcal vaccine group B (15:P1.3) outer membrane protein vaccine in Iquique, Chile. Vaccine 1995;13: 821-9.

83. Bulhões MM. Nota da Comissão Nacional de Meningites. Ministério da Saúde do Brasil, 1993.

84. Feldman HA. Some recollections of the meningococcal diseases. JAMA 1972; 220: 1107-12.

85. Jenison AS, Lemon SM, Baker LN, et al. Quantitative analysis of hepatitis B virus in saliva and semen of chonically infected homosexual men. J Infect Dis 1987; 156: 299 .

86. Petersen NJ, Barret DH, Blond WW, et al. Hepatitis B surface antigen in saliva, impetiginuos lesions, and environment in two remote Alaskan villages. Appl Environ Microbiol 1976; 32: 7572.

87. Shikata T, Karasawa T, Abe K, et al. Hepatitis B antigen and infectivity of hepatitis B virus. J Infect Dis 1977; 136: 571 .

88. Bond WW, Favero MS, Petersen NJ, et al. Survival of hepatitis B virus after drying and storage for one week. Lancet 1981; 1: 550.

89. Moyer LA, Alter MJ, Favero MS. Hemodialysis-associated hepatitis B: revised recommendations for sorologic screening. Seminars in Dialysis 1990; 3: 201.

90. Villarejos VM, Visona KA, Gutierrez A.. Role of saliva, urina and feces in the transmission of type B hepatitis. N Engl J Med 1974; 281: 1375-8.

91. Bancroft WH, Snitban R, Scott RM, et al. Transmission of hepatitis B virus to gibbons by exposure to human saliva containing hepatitis B surface antigen. J Infect Dis 1977; 135: 79-85.

92. Krugman S, Giles JP, Hammond J. Infectious hepatitis: evidence for two distintive clinical, epidemiological, and immunological types of infection. JAMA 1967; 200: 365-73.

93. Piazza M, Cicciatore L, Molinari V, et al. Hepatitis B not transmissible by via fecal-oral route. Lancet 1975; 2: 706.

94. Scott RM, Snitbhan R, Bancroft WH, et al. Experimental transmission of hepatitis B virus by semen and saliva. J Infect Dis 1980; 142: 67-71.

95. Grady GF, Lee VA, Prince AM, et al. Hepatitis B immune globulin for accidental exposures among medical personnel: final report of a multicenter controlled trial. J Infect Dis 1978; 138: 625-38.

96. Anonymous. Type B hepatitis after needle-stick exposures: prevention with hepatitis B immune globulin: final report of the Veterans Administration Cooperative Study. Ann Intern Med 1978; 88: 285.

97. Henderson DK. Postexposure prophylaxis for occupational exposures to hepatitis B, hepatitis C, and human immunodeficiency virus. Surg Clin North Am 1995; 6: 1175-87.

98. CDC. Update on Adult Immunization Recommendations of the Immunization Practices Advisory Committee (ACIP). MMWR Morb Mortal Wkly Rep 1991 40(RR-12): 1-52.

99. Carrilho FJ, França AVC, Silva LC Laudanna AA. Viral hepatitis prophylaxis Rev Hosp Clin Fac Med S Paulo 1996; 51: 203-10.

100. Rumi MG, Romeo R, Bortolini M, et al. Immunogenicity of a yeast-recombinant hepatitis B vaccine in high-risk children. J Med Virol 1989; 27: 48-51.

101. Assateerawatt A, Tanphaichitr VS, Suvatte V, In-ngarm L. Immunogenicity and protective efficacy of low dose recombinant DNA hepatitis B vaccine in normal and high-risk neonates. Asian Pac J allergy Immunol 1991; 9: 89-93.

102. Borcic B, Gasparovi, Mihaljevic I, Aleraj B, Margan IG. Reactivity and immunogenicity of Enrix B, the recombinant DNA vaccine against hepatitis B. Acta Med Iugus 1989; 43: 247-54.

103. Butterly L, Watkins E, Dienstag JL. Recombinant-yeast-derived hepatitis B vaccine in healthy adults: savety and low-year immunogenicity of early investigative lots of vaccine. J Med Virol 1989; 27: 155-9.

104. Ferreira CR, Yoshida CF, Mercadante LA, et al. Immunization against hepatitis B in children from endemic zone: evaluation of the antibody response against the DNA recombinant vaccine (Engerix B-20 mcg). Rev Inst Med Trop São Paulo 1993; 35: 89-92.

105. Hayashi J, Kashiwagi S, Kajiyama W. Comparison of results of recombinant and plasma-derived hepatitis B vaccines in Japonese nursery-school children. J Infect 1988; 17: 49-55.

106. Polywka S, Gatermann S, von Wulffen H, Laufs R. Evaluation of the efficacy of a recombinant hepatitis B vaccine. Immun Infect 1988; 16: 175-8. 
107. Scheiermann N, Gesemann KM, KreuzfelderE, Paar D. Effects of a recombinant yeast-derived hepatitis B vaccine in healthy adults. Postgrad Med J 1987; 63 : 115-9.

108. Wiedermann G, Ambrosch F, Kremsner P, et al. Reactogenicity and immunogenicity of different lots of a yeast-derived hepatitis B vaccine. Postgrad Med J 1987; 63(supp 2): 109-13.

109. Hadler SC, Margolis HS. Hepatitis B immunization: vaccine types, efficacy, and indications for immunization. In: Remington JS, Swartz MN, eds: Current Topics in Infectious Diseases. Boston: Blackwell Scientific Publications 1992: 282.

110. Wainwright RB, Bulkow LR, Parkinson AJ, Zanis C, McMahon BJ. Protection provided by hepatitis B vaccine in a Yupik Eskimo population. results of a 10year study. J Infect Dis 1997; 3: 674-7.

111. Zannolli R, Morgese G. Hepatitis B vaccine: current issues. Ann Pharmacother 1997; 9: 1059-67.

112. Hadler SC, Francis DP, Maynard JE, et al. Long term immunogenicity and efficacy of hepatitis B vaccine in homosexual men. N Engl J Med 1986; 315: 209-14.

113. CDC. Suboptimal response to hepatitis B vaccine given by injection into the buttock. MMWR Morb Mortal Wkly Rep 1985; 34: 105-13.

114. Dienstag JL, Stevens CE, Bhan AK, et al. Hepatitis B vaccine administered to chronic carriers of hepatitis B surface antigen. Ann Intern Med 1982; 96: 575-9.

115. Palmovi D, Crnjakovi, Palmovi J. Prevention of hepatitis B virus (HBV) infection in health-care workers after accidental exposure: a comparison of two prophylactic schedules. Infection 1993; 1: 42-5.

116. Organización Mundial de la Salud. Hepatitis vírica. Série de Informes Técnicos 1973; 512: 7-57.

117. Glaser JB, Nadler JP. Hepatitis B virus in a cardiopulmonary resuscitation training course: risk of transmission from a surface antigen-positive participant. Arch Intern Med 1985; 145: 1653-5.

118. Anonymous. Lack of transmission of hepatitis B to humans after oral exposure to hepatitis B surface antigen-positive saliva. MMWR Morb Mortal Wkly Rep 1978; 27: 247-8.

119. Osterholm MT, Bravo ER, Crosson JT, et al. Lack of transmission of hepatitis type B after oral exposure to HBsAg-positive saliva. Br Med J 1979; 2: 1263-4.

120. Numata N, Ohori H, Hayakawa Y, Saitoh Y, Tsunoda A, Kanno A. Demonstration of hepatitis $\mathrm{C}$ virus genome in salive and urine of patients with type $\mathrm{C}$ hepatitis: usefulness of a single round polymerase chain reaction method for detection of the HCV genome. J Med Virol 1993; 41: 120-8.

121. Couzigou P, Richard L, Dumas F, Schouler L, Fleury H. Detection of HCV-RNA in saliva of patients with chronic hepatitis C. Gut 1993; 34(2 suppl); 559-60.

122. Puchhmmer-StocklE, MorW, Kundi M, HeinzF, Hofmann H, Kunz C. Prevalence of hepatitis-C virus in serum and throat washings of children with chronic hepatitis. J Med Virol 1994; 43: 143-7.

123. CDC. Recommendations for prevention and control of hepatitis $\mathrm{C}$ virus (HCV) infection and HCV-related chronic disease. MMWR Morb Mortal Wkly Rep 1998; 47 (RR-19): 1-39.

124. Alter MJ.Epidemiology of hepatitis C in the West. Semin Liver Dis 1995; 15: 5-14

125. Liddle C. Hepatitis C. Anaesth Intensive Care 1996; 24: 180-3.

126. Poynard T, Bedossa P, Opolon P. Natural history of liver fibrosis progression in patients with chronic hepatitis C. Lancet 1997; 349: 825-32.

127. Silva L, Paraná R, Mota E, et al. Prevalence of hepatitis $C$ virus in urban and rural populations of northeast Brazil-pilot study. Arq Gastroenterol 1995; 4: 168-71.

128. McCormack AP, Damon SK, Eisemberg MS. Disagreeable physical characteristics affeting bystander CPR. Ann Emerg Med 1989; 18: 283-5.

129. Piazza M, Chirianni A, Picciotto L, et al. Passionate kissing and microlesions of the oral mucosa: possible role in AIDS transmission. JAMA 1989; 261: 244-5.

130. CDC. Risk of acquiring hepatitis $\mathrm{C}$ for health care workers and recommendations for prophylaxis and follow-up after occupational exposure. Hepatitis surveillance report no. 56. Atlanta, Georgia: US Department of Health and Human Services, Public Health Service 1995: 3-6.

131. Puro V, Petrosillo N, Ippolito G, Italian Study Group on Occupational Risk of $\mathrm{HIV}$ and Other Bloodborne Infections. Risk of hepatitis $\mathrm{C}$ seroconversion after occupational exposures in health care workers. Am J Infect Control 1995; 23 : 273-7.

132. Lanphear BP, Linnemann CC Jr, Cannon CG, DeRonde MM, Pendy L, Kerley LM. Hepatitis $C$ virus infection in health care workers: risk of exposure and infection. Infect Control Hosp Epidemiol 1994; 15: 745-50.

133. Mitsui T, Iwano K, Masuko K, et al. Hepatitis C virus infection in medical personnel after needle-stick accident. Hepatology 1992; 16: 1109-14.

134. Sartori M,La Terra G, Aglietta M, Manzin A, Navino C, Verzetti G. Transmission of hepatitis C via blood splash into conjunctiva. Scand J Infect Dis 1993; 25: $270-1$

135. Ippolito G, Puro V, Petrosillo N, et al. Simultaneous infection with HIV and hepatitis $\mathrm{C}$ virus following occupational conjunctival blood exposure. JAMA 1998; 280: 28.

136. CDC. Recommendations for follow-up of health-care workers after occupational exposure to hepatitis C virus. MMWR Morb Mortal Wkly Rep 1997; 26: 603-6.
137. CDC. Recommendations for prevention and control of hepatitis $\mathrm{C}$ virus (HCV) infection and HCV-related chronic disease. MMWR Morb Mortal Wkly Rep 1998; 47(RR-19): 1-39.

138. Alter MJ, Jett BW, Polito AJ, et al. Analysis of the role of hepatitis C virus in transfusion-associated hepatitis. In: Hollinger FB, Lemon SM, Margolis HS, eds. Viral Hepatitis and Liver Disease. Baltimore: Williams and Wilkins, 1991: 396-402.

139. Alter MJ, Margolis HS, Krawczynski K, Judson, FN, Mares A, Alexander WJ. The natural history of community-acquired hepatitis $\mathrm{C}$ in the United States. N Engl J Med 1992; 327: 1899-905.

140. Spengler U, Lechmann M, Irrgang B, Dumoulin FL, Sauerbruch T. Immune responses in hepatitis C virus infection. J Hepatol 1996; 24(suppl 2): 20-5.

141. Farci P, Alter HJ, Govindarajan S, et al. Lack of protective immunity against reinfection with hepatitis C virus. Science 1992: 258; 135-40.

142. Choo Q-L, Kuo G, Ralston R, et al. Vaccination of chipanzees against infection by the hepatitis C virus. Proc Nati Acad Sci USA 1994; 91: 1294-8.

143. Farci P, Alter HJ, Wong DC, et al. Prevention of hepatitis C virus infection in chipanzes after antibody-mediated in vitro neutralization. Proc Nat Acad Sci USA 1994; 91: 7792-6.

144. Farci P, Shimoda A, Wong D, et al. Prevention of HCV infection in chipanzees by hyperimmune serum against the hypervariable region (HRV1): emergence of neutralization escape mutants in vivo. Hepatology 1995; 22: 220

145. Krawczynski K, Alter MJ, Tankersly DL, et al. Studies on the prevalence and efficacy of hepatitis C immunoglobulins (HCIG) in experimental hepatitis C infection. Hepatology 1993; 18: 110A.

146. Schiff ER. Hepatitis C among health care providers: risk factors and possible prophylaxis. Hepatology 1992; 16: 1300-1.

147. Gerberding JL, Henderson DK. Management of ocupational exposures to blood-borne pathogens: hepatitis B virus, hepatitis $\mathrm{C}$ virus, and human imunnodeficiency virus. Clin Infect Dis 1992; 14: 1179-85.

148. PHLS Hepatitis Subcommitee. Hepatitis C virus: guidance on the risks and current manegement of occupational exposure. Commun Dis Rep CDR Rev 1993; 3: R135-R139.

149. Noguchi S, Sata M, Suzuki H, Ohba K, Mizokami M, Tanikawa K. Early therapy with interferon for acute hepatitis $\mathrm{C}$ acquired through a needlestick. Clin Infect Dis 1997; 5: 992-4.

150. Takagi H, Uehara M, Kakizaki S, et al. Accidental transmission of HCV and treatment with interferon. J Gastroenterol Hepatol 1998; 3: 238-43.

151. Perras ST, Poupard JA, Byrne EB, Nast PR. Lack of transmission of hepatitis nonA, non-B by CPR manikins. N Engl J Med 1980; 302: 118-9.

152. Fox PC, Wolff A, Yeh CK, et al. Saliva inhibits HIV-1 infectivity. J Am Dent Assoc 1988; 116: 635-7.

153. Friedland GH, Saltzman BR, Roger MF, et al. Lack of transmission of HTLV III/ LAV infection to household contacts of patients with AIDS-related complex with oral candidiasis. N Engl J Med 1986; 134: 344-9.

154. Marcus R and the Cooperative needle stick surveillance group. Surveillance of heath care workers exposed to blood from patients infected with human immunodeficiecy virus. N Engl J Med 1988; 319: 1118-23.

155. Berry AG, Greene ES. The risk of needlestick injuries and needlestick-transmitted diseases in practice of anesthesiology. Anesthesiology 1992; 77: 1007-21.

156. Arend CF. HIV transmission and mouth-to-mouth ventilation: a rational approach. eBMJ, 1998. Available at www.bmj.com/cgi/eletters/316/7148/1870\#EL2.

157. UNAIDS/WHO Epidemiological Fact Sheet on HIV/AIDS and sexually transmitted diseases. June 1998. Available at www.who.int/emc-hiv/global_report/data/tab1.xls.

158. IBGE. Contagem da População. Sistema IBGE de Recuperação Automática. SIDRA 97. Available at www.sidra.ibge.gov.br/

159. Bell DM. Occupational risk of human immunodeficiency virus infection in healthcare workers: an overview. Am J Med 1997; 102(suppl 5B): 9-15.

160. Tokars JI, Marcus R, Culver DH, et al. Survaillance of HIV infection and zidovudine use among health care workers after occupational exposure to HIVinfected blood. Ann Inter Med 1993; 118: 913-9.

161. Ippolito G, Puro V, De Carli G, the Italian Study Group on Occupational Risk of HIV Infection. The risk of occupational human immunodeficiency virus infection in health care workers. Arch Intern Med 1993; 153: 1451-8.

162. CDC. Update: human immunodeficiency virus infections in health-care workers exposed to blood of infected patients. MMWR Morb Mortal Wkly Rep 1987; 36 : $285-9$

163. Heller RF, Steele PL, Fisher JD, Alexander HM, Dobson AJ. Success of cardiopulmonary resuscitation after heart attack in hospital and outside hospital. Br Med J 1995; 311: 1332-6.

164. CDC. Public Health Service guidelines for the management of health-care worker exposures to HIV and recommendations for postexposure prophylaxis. MMWR Morb Mortal Wkly Rep 1998; 47(RR-7): 1-33.

165. CDC. Transmission of HIV possibly associated with exposure of mucous membrane to contaminated blood. MMWR Morb Mortal Wkly Rep 1997; 64: $620-3$ 
166. Illa RV. Possible salivary transmission of AIDS: case report. In: Abstract of the first international symposium on oral AIDS. Montreal 1989: 3-6.

167. Fultz PN. Components of saliva inactivate human immunodeficiency virus. Lancet 1986; 2: 215

168. Busch MP, Satten GA. Time course of viremia and antibody seroconversion following human immunodeficiency virus exposure. Am J Med 1997; 102(suppl5B): 117-24.

169. Chamberland ME, Ciesielski CA, Howard RJ, Fry DE, Bell DM. Occupational risk of infetion with human immunodeficiency virus. Surg Clin North Am 1995; 6: 1057-70.

170. Fahey BJ, Beekman SE, Schmitt J, et al. Managing ocupational exposures to HIV1 in the health care workplace. Infect Control Hosp Epidemiol 1993; 14: 405-12.

171. Martin LN, Murphey-Corb M, Soike KF, Davison-Fairburn B, Baskin GB Effects of initiation of 3'-azido,3'-deoxythymidine (zidovudine) treatment at different times after infection of rhesus monkeys with simian immunodeficiency virus. J Infect Dis 1993; 168: 825-35.

172. McClure HM, Anderson DC, Ansari AA, Fultz PN, Klumpp SA, Schinazi RF. Nonhuman primate models for evaluation of AIDS therapy. In: AIDS: anti-HIV agents, therapies and vaccines. Ann N Y Acad Sci 1990; 616: 287-98.

173. Böttiger D, Johansson N-G, Samuelsson B, et al. Prevention of simian immunodeficiency virus, SIV sm, or HIV-2 infection in cynomolgus monkeys by pre- and postexposure administration of BEA-005. AIDS 1997; 11: 157-62.

174. Shih C-C, Kaneshima H, Rabin L, et al. Postexposure prophylaxis with zidovudine suppresses human immunodeficiency virus type 1 infection in SCID-hu mice in a time-dependent manner. J Infect Dis 1991; 163: 625-7.

175. Tsai C-C, Follis KE, Sabo A, et al. Prevention of SIV infection in macaques by (R)9-(2-phosphonylmethoxypropyl) adenine. Science 1995; 270: 1197-9.

176. CDC. Case-control study of HIV seroconversion in health-care workers after percutaneous exposure to HIV-infected blood-France, United Kingdom, and United States, January 1988-August 1994. MMWR Morb Mortal Wkly Rep 1995; 44: 929-33.

177. Connor EM, Sperling RS, Gelber R, et al. Reduction of maternal-infant transmission of human immunodeficiency virus type 1 with zidovudine treatment. $\mathrm{N}$ Engl J Med 1994; 331: 1173-80.

178. Cardo DM, Culver DH, Ciesielski CA, et al. A Case-Control Study of HIV Seroconversion in Health Care Workers after Percutaneous Exposure. N Engl J Med 1997; 337: 1485-90.

179. Manion DJ, Hirsch MS. Combination chemotherapy for human immunodeficiency virus-1. Am J Med 1997; 102(suppl 5B): 76-80.

180. Lafeuillade A, Poggi C, Tamalet C, Profizi N, Tourres C, Costes O. Effects of a combination of zidovudine, didanosine, and lamivudine on primary human immunodeficiency virus type 1 infection. J Infect Dis 1997; 175: 1051-5.

181. CDC. Birth outcomes following zidovudine therapy in pregnant women. MMWR Morb Mortal Wkly Rep 1994; 43: 409,415-6.

182. White A, Eldridge R, Andrews E, the Antiretroviral Pregnancy Registry Advisory Committee. Birth outcomes following zidovudine exposure in pregnant women: the Antiretroviral Pregnancy Registry. Acta Paediatr Suppl 1997; 421: 86-8.

183. Culnane M, FowlerMG, LeeS, et al. Evaluation for late effects of in utero(IU)ZDV exposure among uninfected infants born to HIV+ women enrolled in ACTG 076 and 219. Clin Infect Dis 1997; 25: 445.

184. Johnson MA, Goodwin C, Yuen GJ, et al. The pharmacokinetics of 3TC administered to HIV-1 infected women (pre-partum, during labour and postpartum) and their offspring. In: Proceedings from the XI International Conference on AIDS, Vancouver 1996; I: 249-50.

185. Moodley J, Moodley D, Pillay K, et al. Antiviral effect of lamivudine alone and in combination with zidovudine in HIV-infected pregnant women. In: Abstracts of the 4th Conference on Retroviruses and Opportunistic Infections. Washington D.C. 1997: 176.
186. Ippolito G, Puro V, the Italian Registry of Antiretroviral Prophylaxis. Zidovudine toxicity in uninfected healthcare workers. Am J Med 1997; 102(suppl 5B): 58-62.

187. Tokars JI, Marcus R, Culver DH, et al. Surveillance of HIV infection and zidovudine use among health care workers after occupational exposure to HIV infected blood. Ann Intern Med 1993; 118: 913-9.

188. Forseter G, Joline C, Wormser GP. Tolerability, safety, and acceptability of zidovudine prophylaxis in health care workers. Arch Intern Med 1994; 154 2745-9.

189. Wang SA, the HIV PEP Registry Group. Human immunodeficiency virus (HIV) postexposure prophylaxis (PEP) following occupational HIV exposure: findings from the HIV PEP registry [Abstract 482]. In: Program and abstracts of the Infectious Diseases Society of America 35th annual meeting. Alexandria: Infectious Diseases Society of America 1997: 161.

190. Steger KA, Swotinsky R, Snyder S, Craven DE. Recent experience with postexposure prophylaxis (PEP) with combination antiretrovirals for occupational exposure (OE) to HIV [Abstract 480]. In: Program and abstracts of the Infectious Diseases Society of America 35th annual meeting. Alexandria: Infectious Diseases Society of America 1997: 161.

191. Beekmann R, Fahrner R, Nelson L, Henderson DK, Gerberding JL. Combination post-exposure prophylaxis (PEP): a prospective study of HIV-exposed health care workers (HCW) [Abstract 481]. In: Program and abstracts of the Infectious Diseases Society of America 35th annual meeting. Alexandria: Infectious Diseases Society of America 1997: 161

192. Reis II. Bíblia Sagrada, capítulo 4, versículo 34.

193. Safar P. Ventilatory efficacy of mouth to mouth artificial respiration: Airway obstrction during manual and mouth to mouth artificial respiration. JAMA 1958; 167: 335-41.

194. Safar P, Escarraga LA, Elam JO. Comparison of mouth-to-mouth and mouth-toairway methods of artificial respiration with the chest-pressure arm-lift methods. N Engl J Med 1958; 258: 671-7.

195. Safar P, Brown TC, Holtey WJ, et al. Ventilation and circulation with closedchest cardiac massage in man. JAMA 1961; 176: 574-6.

196. Safar P. The failure of manual artificial respiration. J Appl Physiol 1959; 4: 84-8.

197. Cohen TJ, Tucker KJ, Lurie KG, et al. Active compression-decompression: a new method of cardiopulmonary resuscitation. JAMA 1992; 267: 2916-23.

198. van Hoeyweghen RJ, Bossaert LL, Mullie A, et al. Quality and efficiency of bystander CPR. Resuscitation 1993; 26: 47-52.

199. Bossart L, Vanhoeyweghen R, Belgiam Cerebral Study Group. Bystanders cardiopulmoanry resuscitation (CPR) in out-of-hospital cardiac arrest Resuscitation 1989; 17(suppl): S55-S69.

200. van Dyke RB, Spector AS. Transmission os herpes simplex virus type I to a newborn infant during endotracheal suctioning for meconium aspiration. Pediatr Infect Dis 1984; 3: 153-6.

201. Emergency Cardiac Care Commitee Heart and Stroke Foundation of Canada. Position Statement. Disease transmission and cardiopulmoray resuscitation. Can Med Assoc J 1990; 143: 1007-8.

202. Valenzuela TD, Hooton TM, Kaplan EL, Schlievert P. Transmission of 'Toxic Strep' Syndrome from an infected child to a firefighter during CPR. Ann Emerg Med 1991; 20: 90-2.

203. American Heart Association. Guidelines for Cardiopulmonary Resuscitation and Emergency Cardiac Care. Adult Basic Life Support. JAMA 1992; 268: 2184 98.

204. Basic Life Support Working Group of the European Resuscitation Council. The 1998 European Resuscitation Council guidelines for adult single rescuer basic life support. Br Med J 1998; 316: 1870-6. 